\title{
A new baseline for fascioliasis in Venezuela: lymnaeid vectors ascertained by DNA sequencing and analysis of their relationships with human and animal infection
}

M Dolores Bargues ${ }^{1}$, L Carolina González ${ }^{1,2}$, Patricio Artigas ${ }^{1}$ and Santiago Mas-Coma ${ }^{1 *}$

\begin{abstract}
Background: Human and animal fascioliasis poses serious public health problems in South America. In Venezuela, livestock infection represents an important veterinary problem whereas there appear to be few human cases reported, most of which are passively detected in health centres. However, results of recent surveys suggest that the situation may be underestimated in particular areas. To obtain a baseline for future fascioliasis assessment, studies were undertaken by means of rDNA ITS-2 and ITS-1 and mtDNA cox1 sequencing to clarify the specific status of Venezuelan lymnaeids, their geographical distribution and fascioliasis transmission capacity, by comparison with other American countries and other continents.

Results: Results obtained completely change the lymnaeid scenario known so far. The relatively rich lymnaeid fauna of Venezuela has been proven to include (i) Lymnaea meridensis and L. neotropica as the only native members, (ii) L. cubensis and Pseudosuccinea columella introduced from the Caribbean area, and (iii) Galba truncatula and $L$. schirazensis introduced from the Old World. The absence of representatives of the stagnicoline and Radix groups is remarkable. Four species are fascioliasis vectors: G. truncatula, L. cubensis and L. neotropica, which have the capacity to give rise to human endemic areas, and P. columella, which is a source of animal infection and is responsible for the spread of disease. Vector capacity in the apparently highland endemic $L$. meridensis is to be confimed, although may be expected given its phylogenetic relationships. Similarly as elsewhere, the non-transmitting L. schirazensis has been confused with L. cubensis, also with G. truncatula and possibly with L. neotropica.
\end{abstract}

Conclusions: The new scenario leads to the re-opening of many disease aspects. In Venezuela, altitude appears to be the main factor influencing fascioliasis distribution. Human infection shows an altitude pattern similar to other Andean countries, although a differing highland/lowland impact on animal infection does not appear evident. The overlap of G. truncatula, L. cubensis and probably also L. neotropica in temperate and cold zones suggests a higher risk for human infection in mid and high altitude areas. A lymnaeid species mapping by means of DNA markers becomes a priority to determine human and animal fascioliasis distribution in Venezuela, owing to the importance of lymnaeid vectors in defining transmission and epidemiological patterns.

\footnotetext{
* Correspondence: S.Mas.Coma@uv.es

'Departamento de Parasitología, Facultad de Farmacia, Universidad de

Valencia, Av. Vicente Andrés Estellés s/n, 46100 Burjassot - Valencia, Spain

Full list of author information is available at the end of the article
} 


\section{Background}

Fascioliasis is a pathogenic liver parasitosis caused by fasciolid flukes which affects humans and livestock species almost everywhere [1,2]. In the last two decades, this disease has emerged in many countries of Latin America, Europe, Africa and Asia [1,3]. This emergence phenomenon has partly been related to climate change $[4,5]$, given the high dependence of both fasciolid larval stages and their freshwater lymnaeid snail vectors on climatic and environmental characteristics [6].

The infectivity of the metacercarial infective stage of isolates from different livestock species isolates have been shown to be similar $[7,8]$, whereas the lymnaeid vector species represent a crucial factor for the epidemiology of the disease $[9,10]$. Geographical distribution, prevalences and intensities of both human and animal infection pronouncedly depend on the ecological characteristics (population dynamics, anthropophylic characteristics, type of water bodies, etc.) of the lymnaeid species involved in the transmission. Different lymnaeid species appear, therefore, linked to the different transmission patterns and epidemiological scenarios of this very heterogeneous disease in humans [2,11]. Thus, similarly as in other vector-borne diseases, this relationship supports the use of lymnaeids as disease biomarkers and becomes useful for mathematical modelling and remote sensing geographical information system (RS-GIS) tools for the control of fascioliasis $[12,13]$.

South America stands out due to the human endemic areas described in many Andean countries, including high prevalence and intensity in humans caused by Fasciola hepatica, such as in Chile [14], Bolivia [15-17], Peru $[18,19]$ and Ecuador [20]. In Argentina the human fascioliasis situation seems to be underestimated [21] and in Colombia appropriate studies in risky rural areas are still pending [22].

In Venezuela, livestock infection represents an important veterinary problem in many parts of the country (Figure 1) [23]. On the contrary, human cases reported appear to be relatively few, around 50. Most of these cases have been passively detected in health centres. However, results of recent surveys give cause for concern and also indicate that the situation may be underestimated in certain areas [23]. All in all, the insufficient present fragmentary knowledge on fascioliasis suggests the need to ascertain the lymnaeid vector species present in the country, their geographical distribution, ecological characteristics and population dynamics, in order to furnish the baseline on which to design and launch the adequate studies on the disease in both humans and animals.

Only two lymnaeid species have been traditionally reported to be present in Venezuela: Lymnaea cubensis and Pseudosuccinea columella [24-27]. The first is a member of the Galba/Fossaria group, a well-known vector of fascioliasis originally described from Cuba and distributed throughout southern North America and the Caribbean [28]. Pseudosuccinea columella is a peculiar, widely dispersed species, believed to be originally from the region of southern North America, Central America and the Caribbean, but which has successfully colonised other continents (South America, Europe, Africa, Oceania) $[29,30]$, and is also an efficient vector leading to increased spread of the disease [31].

This reduced list of lymnaeid species reported in Venezuela changed as the consequence of the collection of specimens of different populations of L. cubensis in Mérida State in March 2000. A preliminary DNA sequencing process suggested that several of these populations belonged to the morphologically very similar species Galba truncatula, with which it may be easily confused, similarly as it happens with other small lymnaeid species $[28,32]$. However, subsequent extensive DNA marker sequencing proved that indeed not only one but several different, yet similar species had been confused under the name of L. cubensis in Venezuela. Additionally, Lymnaea cousini, hithterto only known from Ecuador and Colombia [29], has recently been described and reported in Venezuela $[33,34]$.

However, lymnaeids pose serious specimen classification difficulties when only applying malacological methods such as anatomical studies $[9,10,28,35]$. Moreover, intraspecific variation of shell shape is well marked in lymnaeids, although a genetic component in shell shape has been shown at least in some lymnaeid populations [36]. In the Americas, specimen classification problems are mainly related to the so-called "fossarine" or Galba/Fossaria group of numerous, very similar, usually undifferentiable lymnaeid vector species $[28,32]$, as is the case of the aforementioned L. cubensis, G. truncatula and L. cousini.

The crucial implications of lymnaeid vectors for fascioliasis transmission, epidemiology and control urged the development of new tools to facilitate specimen classification, genetic characterisation of natural populations and laboratory strains, and to elucidate the systematics and taxonomy of the Lymnaeidae. This is the purpose of the worldwide lymnaeid molecular characterisation initiative [2]. Nuclear ribosomal DNA (rDNA) and mitochondrial DNA (mtDNA) markers proved useful for this endeavour in invertebrates in general, although disadvantages and limitations depending on each marker should be taken into account [37]. Their application also showed their usefulness in lymnaeids [10].

The internal transcribed spacers of the rDNA, mainly ITS- 2 and secondarily ITS-1, are the most useful sequences for studies at both specific and supraspecific levels $[2,10,38]$. Similarly as in planorbid vectors of 


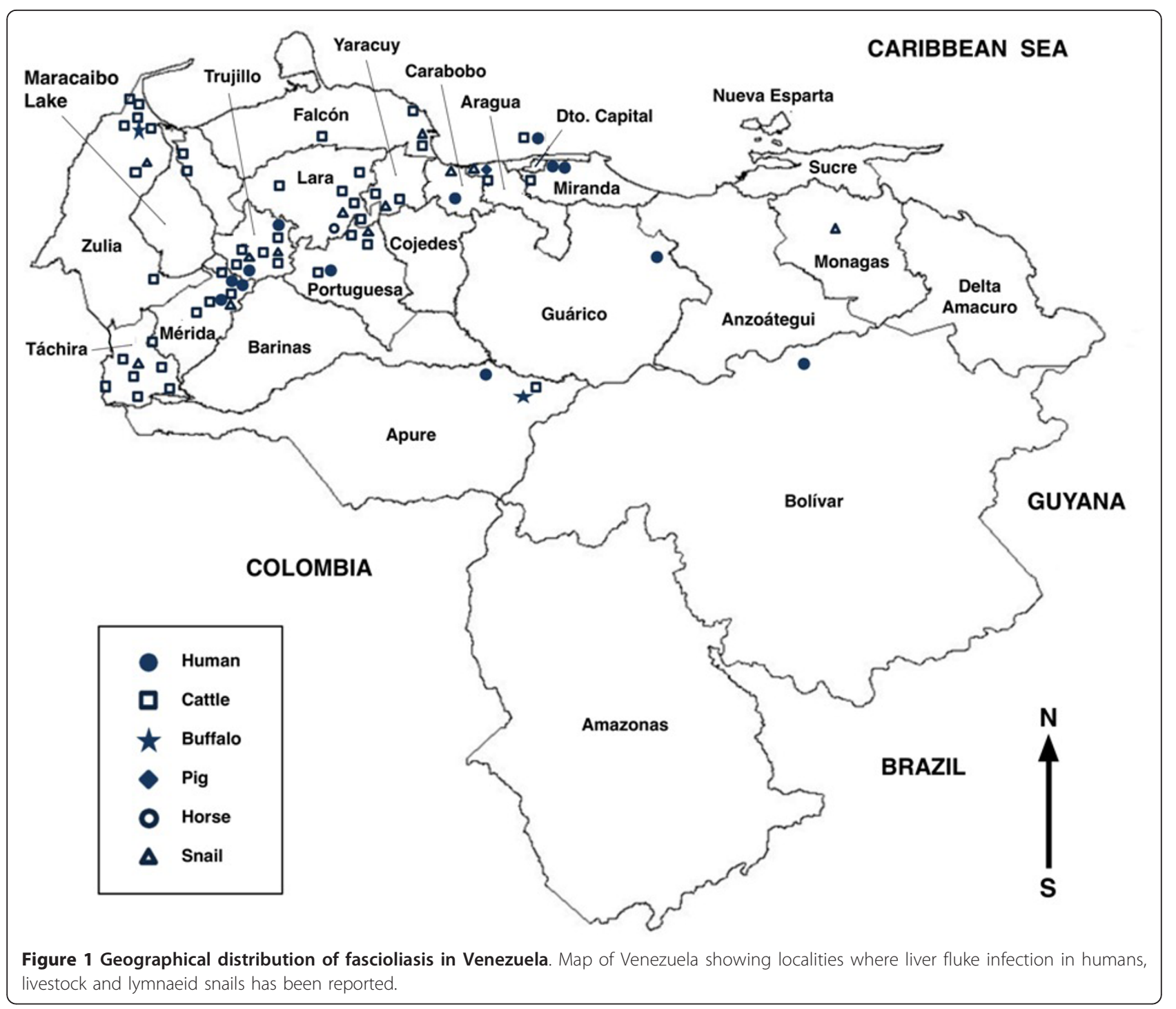

schistosomiasis [39], a fragment of the cytochrome c oxidase subunit I gene (cox 1$)$ of the mtDNA has also been used in lymnaeids [28]. However, its usefulness in lymnaeids has been recommended to be restricted to only population and close species analyses [2], due to saturation of nucleotide positions and problems posed by incomplete gene sequences [37].

The purpose of this present article is to report the results of more than ten years work by means of ITS-2, ITS- 1 and $\operatorname{cox} 1$ sequencing, which are required to clarify the number of lymnaeid species present in Venezuela and to ascertain their systematic status by comparison with lymnaeids not only of neighbouring or geographically near countries but also of different continents. The final analysis offers a completely new spectrum of six lymnaeid species whose composition considerably differs from what has been noted so far. This offers a new baseline on which to design and launch appropriate studies on human and animal fascioliasis in Venezuela henceforth. The implications of this new vector scenario on the disease are finally discussed.

\section{Methods}

\section{Lymnaeid snail materials}

The snail specimens studied were collected in the field, from lymnaeid populations present in geographical areas with human infection and/or animal fascioliasis endemicity. Given the geographical distribution of fascioliasis concentrated in the western and north-western parts of the country (Figure 1), studies focused mainly on lymnaeid populations found in localities of selected endemic Venezuelan states and found at different altitudes, in order to (i) increase probabilities to assure finding all lymnaeid species present and (ii) sequence the lymnaeids found in 
areas where most human cases have been reported. No mixed populations were found. Localities furnishing the lymnaeid specimens sequenced are noted in Table 1. Coordinates and altitudes, types of habitat, month of collection, and number of specimens collected are added for each locality.

Living specimens were fixed in $70 \%$ ethanol immediately after collection in the field and stored in the same fixative until analysis.

Preliminary classification of specimens (Table 1) was, whenever possible, based on shell shape and size and morpho-anatomical characteristics traditionally considered of systematic usefulness, mainly the sexual organs. Unfortunately, sometimes snail softparts were too contracted due to fixation by alcohol $96 \%$ in cold conditions or specimens available were too small to allow a clear anatomical classification and consequently specimens were classified on shell characteristics only. In given cases, specimens were collected and preliminarily classified before 2006, when publications including phenotypic re-assessments of species were not yet available. In other cases, the preliminary classification was only at genus level, because collectors (vets, i.e., non-malacology experts) already knew that there were many species under the term of "cubensis" together with the great difficulties or even sometimes impossibility to diferentiate between species of Galba/Fossaria. Even in a species $a$ priori easily classifiable as $P$. columella [40], its unexpected finding at very high altitude led the collectors to leave its classification open. With regard to Galba/Fossaria species, several recent articles have furnished new complete phenotypic re-descriptions that may help henceforth $[22,28,41-43]$.

\section{Molecular techniques DNA extraction}

DNA was extracted from more than one specimen of a given population when this was deemed necessary for sequence verification. DNA was only isolated from the foot of each snail $[28,44]$. Snail feet fixed in $70 \%$ ethanol were used for DNA extraction procedures. After dissection under a microscope, half of the foot was suspended in $400 \mu \mathrm{l}$ of lysis buffer $(10 \mathrm{mM}$ Tris- $\mathrm{HCl}, \mathrm{pH}$ 8.0, 100 mM EDTA, $100 \mathrm{mM} \mathrm{NaCl}, 1 \%$ sodium dodecyl sulphate SDS) containing $500 \mu \mathrm{g} / \mathrm{ml}$ Proteinase K (Promega, Madison, WI, USA) and digested for $2 \mathrm{hr}$ at $55^{\circ} \mathrm{C}$ with alternate shaking each $15 \mathrm{~min}$. The extraction was then performed with chloroform and DNA was precipitated with isopropyl alcohol. The procedure steps were performed according to methods outlined previously $[9,28,32,45]$. The pellet was dried and resuspended in 30 $\mu$ sterile TE buffer ( $\mathrm{pH}$ 8.0). This suspension was stored at $-20^{\circ} \mathrm{C}$ until use.

\section{DNA sequence amplification}

Each one of the three DNA markers was PCR amplified independently for each lymnaeid specimen and each PCR product was sequenced for a bona-fide haplotype characterisation. The rDNA spacers ITS-2 and ITS-1 were amplified using primers previously described $[9,28,32,46,47]$. A mitochondrial DNA cox 1 gene fragment was amplified using universal primers [48]. Amplifications were generated in a Mastercycle epgradient (Eppendorf, Hamburg, Germany) using 4-6 $\mu$ l of genomic DNA for each $50 \mu \mathrm{l}$ PCR reaction. PCR conditions were 30 cycles of $30 \mathrm{sec}$ at $94^{\circ} \mathrm{C}, 30 \mathrm{sec}$ at $50^{\circ} \mathrm{C}$ and 1 min at $72^{\circ} \mathrm{C}$, preceded by $30 \mathrm{sec}$ at $94^{\circ} \mathrm{C}$ and followed by $7 \mathrm{~min}$ at $72^{\circ} \mathrm{C}$ for ITS- 2 and ITS-1, and by 40 cycles of $30 \mathrm{sec}$ at $90^{\circ} \mathrm{C}, 1 \mathrm{~min}$ at $48^{\circ} \mathrm{C}$ and $1 \mathrm{~min}$ at $72^{\circ} \mathrm{C}$, preceded by $2.5 \mathrm{~min}$ at $94^{\circ} \mathrm{C}$ and followed by $10 \mathrm{~min}$ at $72^{\circ} \mathrm{C}$ for $\operatorname{cox} 1$. Ten $\mu \mathrm{l}$ of each PCR product was checked by staining with ethidium bromide on $1 \%$ Nusieve ${ }^{\circledR}$ GTG agarose (FMC) gel electrophoresis, using the Molecular Weight Marker VI (Boehringer Mannheim) at $0.1 \mu \mathrm{g} \mathrm{DNA} / \mu \mathrm{l}$ as control.

\section{Purification and quantification of PCR products}

Primers and nucleotides were removed from PCR products by purification on Wizard ${ }^{\mathrm{TM}}$ PCR Preps DNA Purification System (Promega, Madison, WI, USA) according to the manufacturer's protocol and resuspended in $50 \mu \mathrm{l}$ of $10 \mathrm{mM}$ TE buffer ( $\mathrm{pH}$ 7.6). The final DNA concentration was determined by measuring the absorbance at 260 and $280 \mathrm{~nm}$

\section{DNA sequencing}

The sequencing of the complete rDNA ITS-2 and ITS-1 and the fragment of the mtDNA cox 1 gene was performed on both strands by the dideoxy chain-termination method [49]. It was carried out with the Taq dye-terminator chemistry kit for ABI 3730 DNA Analyzer (Applied Biosystems, Foster City, CA, USA), using PCR primers.

\section{Sequence alignments}

Sequences were aligned using CLUSTAL-W version 1.8 [50] and MEGA 4.0 [51], and assembly was made with the Staden Package [52]. Subsequently, minor corrections were manually introduced for a better fit of nucleotide correspondences in microsatellite sequence regions. Homologies were performed using the BLASTN programme from the National Centre for Biotechnology information web site http://www.ncbi.nlm.nih.gov/ BLAST.

\section{DNA haplotype nomenclature}

The codes for the sequences obtained follow the standard nomenclature proposed previously for lymnaeid snails $[2,10,46]$. It shall be noted that haplotype codes are only definitive in the case of complete sequences. When dealing with fragments or incomplete sequences, haplotype codes are provisional. 
Table 1 Nuclear ribosomal and mitochondrial DNA haplotype code identification for lymnaeid species and populations studied from Venezuela

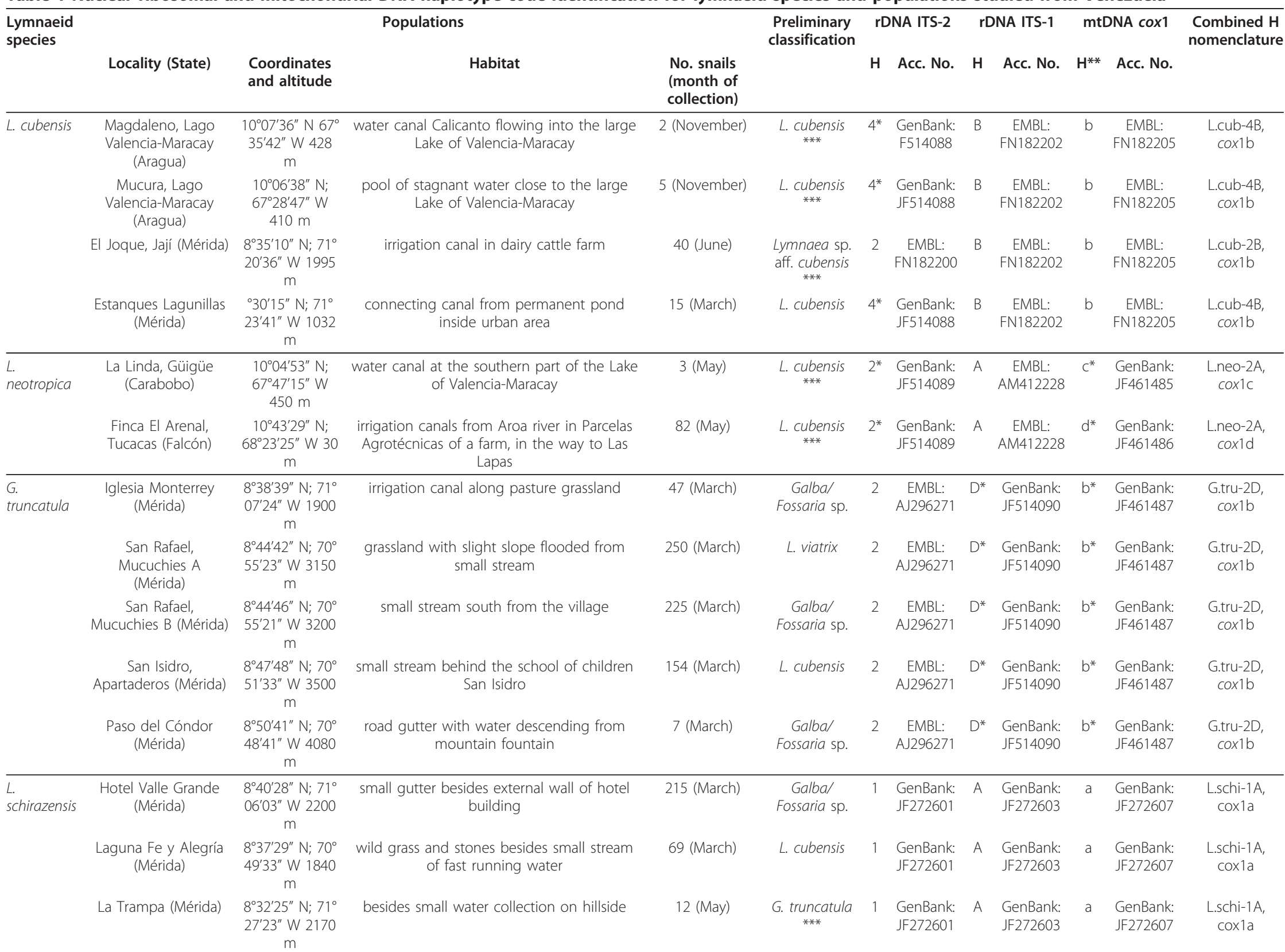


Table 1 Nuclear ribosomal and mitochondrial DNA haplotype code identification for lymnaeid species and populations studied from Venezuela (Continued)

\begin{tabular}{|c|c|c|c|c|c|c|c|c|c|c|c|c|}
\hline $\begin{array}{l}\text { L. } \\
\text { meridensis }\end{array}$ & $\begin{array}{l}\text { Laguna Mucubaji } \\
\text { (Mérida) }\end{array}$ & $\begin{array}{c}8^{\circ} 47^{\prime} 52^{\prime \prime} N ; 70^{\circ} \\
49^{\prime} 32^{\prime \prime} W 3550 \\
\text { m }\end{array}$ & $\begin{array}{c}\text { surroundings and shore of large natural } \\
\text { pool }\end{array}$ & 29 (October) & L. cousini & 1 & $\begin{array}{l}\text { EMBL: } \\
\text { FN598154 }\end{array}$ & $A$ & $\begin{array}{l}\text { EMBL: } \\
\text { FN598159 }\end{array}$ & a & $\begin{array}{l}\text { EMBL: } \\
\text { FN598164 }\end{array}$ & $\begin{array}{l}\text { L.mer-1A, } \\
\text { cox1a }\end{array}$ \\
\hline \multirow[t]{2}{*}{$\begin{array}{l}P . \\
\text { columella }\end{array}$} & $\begin{array}{l}\text { La Linda, Güigüe } \\
\text { (Carabobo) }\end{array}$ & $\begin{array}{l}10^{\circ} 04^{\prime} 53^{\prime \prime} \mathrm{N} ; \\
67^{\circ} 47^{\prime} 15^{\prime \prime} \mathrm{W} \\
450 \mathrm{~m}\end{array}$ & $\begin{array}{l}\text { water canal at the southern part of the Lake } \\
\text { of Valencia-Maracay }\end{array}$ & 2 (May) & P. columella & 2 & $\begin{array}{c}\text { EMBL: } \\
\text { FN598156 }\end{array}$ & $A$ & $\begin{array}{l}\text { EMBL: } \\
\text { FN598160 }\end{array}$ & a & $\begin{array}{c}\text { EMBL: } \\
\text { FN598165 }\end{array}$ & $\begin{array}{l}\text { P.col-2A, } \\
\text { coxia }\end{array}$ \\
\hline & El Valle (Mérida) & $\begin{array}{c}8^{\circ} 38^{\prime} 41^{\prime \prime} N ; 71^{\circ} \\
07^{\prime} 24^{\prime \prime} \text { W } 1930 \\
\text { m }\end{array}$ & $\begin{array}{l}\text { irrigation canal along pasture grassland } \\
\text { close to Iglesia Monterrey }\end{array}$ & 4 (March) & $\begin{array}{l}\text { Lymnaeidae } \\
\text { gen. sp. }\end{array}$ & 1 & $\begin{array}{l}\text { EMBL: } \\
\text { FN598155 }\end{array}$ & A & $\begin{array}{l}\text { EMBL: } \\
\text { FN598160 }\end{array}$ & a & $\begin{array}{c}\text { EMBL: } \\
\text { FN598165 }\end{array}$ & $\begin{array}{l}\text { P.col-1A, } \\
\text { coxia }\end{array}$ \\
\hline
\end{tabular}

$\mathrm{H}=$ haplotype; ${ }^{*}=$ new haplotypes for the corresponding lymnaeid species; ${ }^{* *}=$ only preliminary haplotypes due to incomplete gene sequence; ${ }^{* *}=$ material collected, alcohol-fixed, preliminarily classified and furnished by colleagues 


\section{Sequence comparisons}

The following sequences from GenBank-EMBL have been used for comparison analyses:

- rDNA ITS-2: G. truncatula H1 [EMBL: AJ296271], H2 [EMBL: AJ243017] and H3 (= L. viatrix sensu Ueno et al., 1975; = L. cubensis sensu Ueno et al., 1975) [EMBL: AJ272051] [9,28,47]; L. cubensis H1 [EMBL: AM412223], H2 [EMBL: FN182200] and H3 [EMBL: FN182201] [28,43], L. neotropica [EMBL: AM412225] [28], L. schirazensis H1 [GenBank: JF272601] and H2 [GenBank: JF272602] [43], L. cousini [EMBL: FN598153] and L. meridensis [EMBL: FN598154] [22]; P. columella H1 [EMBL: FN598155] and H2 [EMBL: FN598156] [22] and P. columella [GenBank: AY186751] [53].

- rDNA ITS-1: G. truncatula HA [EMBL: AJ243018], HB [EMBL: AJ296270] and HC (= L. viatrix sensu Ueno et al., 1975; = L. cubensis sensu Ueno et al., 1975) [EMBL: AJ272052] [9,28,47]; L. cubensis HA [EMBL: AM412226], HB [EMBL: FN182202] and HC [EMBL: FN182203] [28,43], L. neotropica [EMBL: AM412228] [28], L. schirazensis HA [GenBank: JF272603] and HB [GenBank: JF272604] [43], L. cousini [EMBL: FN598157] and L. meridensis [EMBL: FN598159] [22]; P. columella HA [EMBL: FN598160] [22] and P. columella [GenBank: AY186751] [53].

- mtDNA cox1 gene: G. truncatula from Spain [EMBL: AM494011] [28] and Germany [GenBank: EU818799] [54]; L. cubensis cox1a [EMBL: AM494009] and cox1b [EMBL: FN182205], L. neotropica cox1a [EMBL: AM494008] and cox1b [EMBL: FN356741] [28,43,55], L. schirazensis cox1a [GenBank: JF272607], cox1b [GenBank: JF272608], cox1c [GenBank: JF272609], and cox1d [GenBank: JF272610] [43], L. cousini [EMBL: FN598161] and L. meridensis [EMBL: FN598164] [22]; P. columella [EMBL: FN598165] [22] and P. columella [GenBank: AY227366] [56].

\section{Phylogenetic inference}

Phylogenetic analysis of ITS- 2 and ITS-1 combined haplotypes was performed with a Maximum Likelihood (ML) approach using PAUP version 4.0b10. ML parameters and the evolutionary model best fitting our dataset were determined using Akaike and Bayesian information criteria (AIC and BIC) [57,58], implemented in jModeltest vesion 0.1.1 [59]. Starting branch lengths were obtained using the least-squares method with ML distances.

To provide an assessment of the reliability of the nodes in the ML tree, three methods were used. First, a bootstrap analysis using 1000 replicates was made with fast-heuristic search in PAUP. Second, a distance-based phylogeny using the neighbour-joining (NJ) algorithm [60] with the ML pairwise distances was obtained and statistical support for the nodes was evaluated with 1000 bootstrap replicates, with and without removal of gapped positions. Third, a Bayesian phylogeny reconstruction procedure was applied to obtain posterior probabilities (BPP) for the nodes in the ML tree, by using the same evolutionary model as above, implemented in MrBayes 3.1 [61] with four chains during $1,000,000$ generations, trees being sampled every 100 generations. The first 1000 trees sampled were discarded ("burn-in") and clade posterior probabilities (PP) were computed from the remaining trees.

Phylogenetic analyses were performed after adding the following reference sequences of rDNA ITS-2 and ITS-1 of lymnaeids stored in the databases: L. (Stagnicola) palustris palustris [EMBL: AJ319620, EMBL: AJ626849]; L. (S.) fuscus [EMBL: AJ319621, EMBL: AJ626856] [9]; Catascopia catascopium [GenBank: AF013143, GenBank: AF013143]; Hinkleyia caperata [GenBank: AF013139, GenBank: AF013139] [62]; Radix auricularia ITS-2 halplotype 1 [EMBL: AJ319628]; $R$. balthica $(=R$. peregra) ITS-2 haplotype 1 [EMBL: AJ319633] [9]. The intergenic region sequence [GenBank: AY030361] including both ITSs of the planorbid species Biomphalaria pfeifferi [63] was used as outgroup.

\section{Results}

Nuclear rDNA ITS- 2 and ITS- 1 and mtDNA cox 1 nucleotide sequence data reported in this paper are available in the GenBank database under the accession numbers noted in Table 1.

\section{Lymnaea cubensis}

Specimens from Magdaleno and Mucura (Aragua State), Estanques Lagunillas and Jají (Mérida State), preliminarily classified as L. cubensis or Lymnaea sp. aff. cubensis, proved to be $L$. cubensis by ribosomal and mitochondrial DNA markers (Table 1).

\section{rDNA ITS-2}

Two haplotypes were found in the populations studied. All specimens from Aragua and Estanques Lagunillas showed identical ITS-2 sequences, of 466 bp and $56.65 \%$ GC content, which is different from the three haplotypes $(\mathrm{H} 1, \mathrm{H} 2$, $\mathrm{H} 3$ ) available in EMBL, and is therefore here added as a new haplotype, L.cub-H4 (Table 1). The great length difference between the haplotypes L.cub-H1, H2 and $\mathrm{H} 3$ is related to a tetranucleotide microsatellite (CTTG) which appears in positions 51-146 of the ITS-2 alignment and which is consecutively repeated 25, 5 and 13 times in L. cubensis $\mathrm{H} 1, \mathrm{H} 2$ and $\mathrm{H} 3$, respectively. The new haplotype $\mathrm{H} 4$ is characterised by the same microsatellite repeat but appearing interruptedly (CTTG) ${ }_{1}$ CATG(CTTG) ${ }_{1} \mathrm{CATG}(\mathrm{CTTG})_{3}$. Nucleotide and microsatellite differences in $L$. cubensis haplotypes ( $\mathrm{H} 1$ to $\mathrm{H} 4)$ are listed in Figure 2. The specimens from Jají population showed an ITS-2 


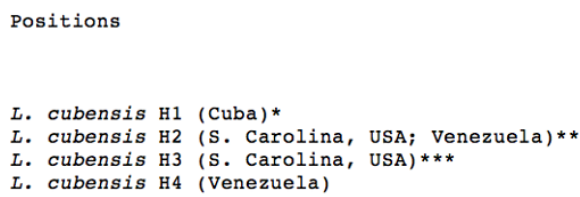

$\begin{array}{llllll}1 & 1111111111 & 1111111111 & 1111111111 & 1111111111 & 111112\end{array}$

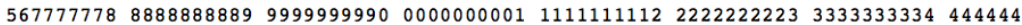
$\begin{array}{lllllllll}644567890 & 1234567890 & 1234567890 & 1234567890 & 1234567890 & 1234567890 & 1234567890 & 123453\end{array}$

TTGCTTGCT TGCTTGCTTG CTTGCTTGCT TGCTTGCTTG CTTGCTTGCT TGCTTGCTTG CTTGCTTGCT CGCTTT

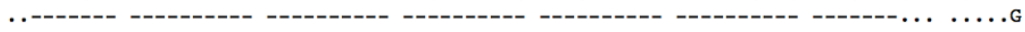

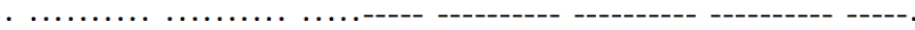
AА

Figure 2 Nucleotide variable positions and microsatellites found in the ITS-2 sequence of the $L$. cubensis populations and haplotypes studied. Position = numbers (to be read in vertical) refer to variable positions obtained in the alignment made with MEGA 4.0. Identical = ;

Indel = -. *EMBL: AM412223; ** EMBL: FN182200; *** EMBL: FN182201.

sequence of $470 \mathrm{bp}$ and $57.02 \%$ GC content, which is identical to L.cub-H2 from Sullivan Island, South Carolina, USA [EMBL: FN182200].

\section{rDNA ITS-1}

All the specimens from the four populations analysed present the same ITS-1 sequence, of $520 \mathrm{bp}$ and a 56.35\% GC content. When compared with the three ITS-1 haplotypes of $L$. cubensis available in EMBL (HA, $\mathrm{HB}, \mathrm{HC}$ ), this ITS-1 proved to be identical to the haplotype L.cub-HB also present in Sullivan Island, South Carolina, USA [EMBL: FN182202].

\section{$m+D N A$ cox 1}

Only one haplotype was detected in all specimens and populations studied, with a length of $672 \mathrm{bp}$ and an AT content of $68,60 \%$. This sequence fits exactly with the previously described L.cub-cox $1 \mathrm{~b}$ from South Carolina, USA [EMBL: FN182205], differing by only one mutation (T/C) with regard to L.cub-cox1a in position 468 of the respective alignment. In the amino acidic sequence alignment (224 aa long), both cox1a and cox1b haplotypes are identical.

\section{Lymnaea neotropica}

Specimens from La Linda (Carabobo State) and Finca el Arenal, Tucacas (Falcón State), preliminarily classified as L. cubensis, proved to be L. neotropica by ribosomal and mitochondrial DNA markers (Table 1).

\section{rDNA ITS-2}

All the specimens showed identical ITS-2 sequence, of 415 bp and a $56.87 \%$ GC content. When compared with the ITS-2 haplotype of $L$. neotropica available in EMBL (H1), the Venezuelan sequence proved to be different, showing a shorter length due to the lack of one microsatellite repeat (AT) in positions 402-403 of the sequence alignment of both ITS- 2 haplotypes. This is the first time that this haplotype has been found and has consequently been deposited in GenBank under the new code L.neo-H2 (Table 1).

\section{rDNA ITS-1}

All specimens studied presented the same ITS-1 sequence of $533 \mathrm{bp}$ and a $56.66 \%$ GC content. This sequence was compared with the ITS-1 haplotype of $L$. neotropica available in EMBL (L.neo-HA) and proved to be identical to this haplotype also present in Peru and Argentina [EMBL: AM412228].

\section{mtDNA cox 1}

Two haplotypes were detected in the populations studied, both identical in length (672 bp) and AT content $(69,64 \%)$ but differing at two variable positions (Figure $3)$. When compared to the other two cox 1 sequence haplotypes of $L$. neotropica available in EMBL (cox1a and $\operatorname{cox} 1 \mathrm{~b}$ ), it proved to be different at 8 variable positions (Figure 3). Therefore, these two new haplotypes have been deposited in GenBank under the provisional codes L.neo-cox 1c and L.neo-cox $1 \mathrm{~d}$ (Table 1). In the amino acidic sequence alignment (224 aa long), both cox 1c and cox $1 \mathrm{~d}$ haplotypes appear to be identical. Amino acidic changes detected between the four $L$. neotropica cox 1 haplotypes only concern one amino acid (G/S) in position 125 (Figure 3). Interestingly, when translated to amino acids, these Venezuelan haplotypes L.neo-cox $1 \mathrm{c}$ and L.neo-cox $1 \mathrm{~d}$ give rise to the same amino acid sequence than the one obtained from the three L. cubensis haplotypes cox $1 \mathrm{a}$, cox $1 \mathrm{~b}$ and cox1c.

\section{Galba truncatula}

Specimens from Iglesia Monterrey, two different populations in San Rafael de Mucuchíes, Apartaderos and Paso del Cóndor (Mérida State), preliminarily classified as Galba/Fossaria sp., L. viatrix or L. cubensis, proved to be G. truncatula by ribosomal and mitochondrial DNA markers (Table 1).

\section{rDNA ITS-2}

All the specimens showed an identical ITS-2 sequence, of $401 \mathrm{bp}$ and a $59.10 \%$ GC content. When compared with the three ITS-2 haplotypes of G. truncatula available in EMBL (H1, H2, H3), this sequence proved to be identical to the previously described ITS-2 haplotype 2 (H2) for G. truncatula [EMBL: AJ243017].

\section{rDNA ITS-1}

All specimens studied showed identical ITS-1 sequence, of $504 \mathrm{bp}$ and a $57.74 \%$ GC content. This sequence was compared with the three ITS-1 haplotypes of G. truncatula available in EMBL (HA, HB, HC) and proved to be different, with a specific mutation $C$ instead of $T$ in position 449 of the ITS-1 haplotype sequence alignment. 


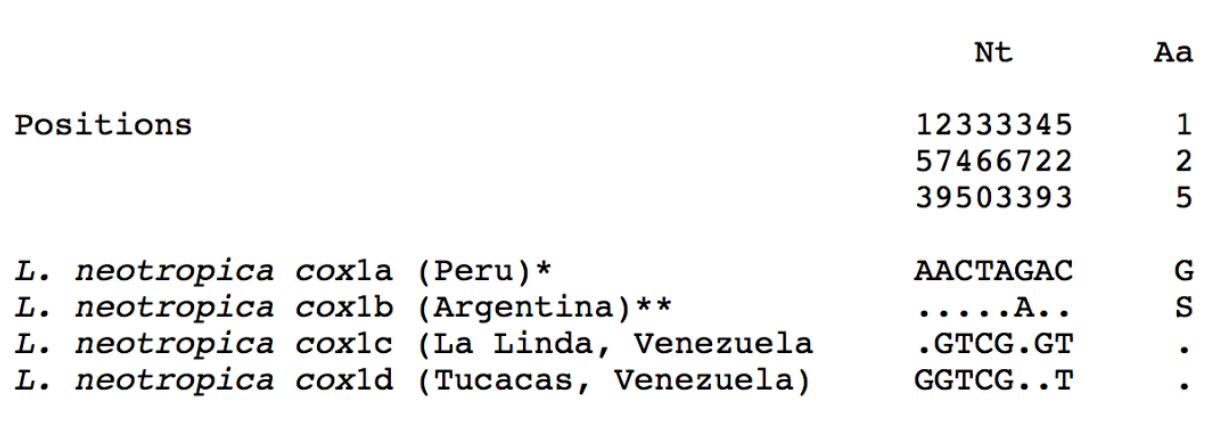

Figure 3 Nucleotide and amino acid differences found in the mtDNA cox 1 sequence of the Lymnaea neotropica populations studied from Venezuela. Position = numbers (to be read in vertical) refer to variable positions obtained in the alignment made with MEGA 4.0. Nt = nucleotides; $\mathrm{Aa}=$ amino acids; Identical $=$; Indel $=-$. Haplotype codes only provisional due to incomplete sequences of the gene. ${ }^{*} E M B L:$ AM494008; **EMBL: FN356741.

This new haplotype has been deposited in GenBank under the code G.tru-HD (Table 1).

\section{mtDNA cox1}

Only one haplotype was detected, being identical in all specimens analysed and including 672 bp and a $68.16 \%$ AT content. This haplotype proved to be different by showing 27 specific mutations when compared to the other cox 1 sequence fragments of similar length of $G$. truncatula available in EMBL (Figure 4). The new haplotype has therefore been deposited in GenBank under the provisional code G.tru-cox1b (Table 1). However, both cox $1 \mathrm{a}$ and cox $1 \mathrm{~b}$ haplotypes were identical in the 224-aa-long amino acidic sequence alignment, which means that the 27 mutations are all silent.

\section{Lymnaea schirazensis}

Snail specimens collected from Hotel Valle Grande, Laguna Fe y Alegría and La Trampa (Mérida State), preliminarily classified as Galba/Fossaria sp., L. cubensis or G. truncatula, proved to be L. schirazensis after ribosomal and mitochondrial DNA marker sequencing (Table 1).

\section{rDNA ITS-2}

All the specimens analysed presented the same ITS-2 sequence, of $444 \mathrm{bp}$ and a $53.82 \%$ GC content. When compared to the two ITS-2 haplotypes of L. schirazensis available in GenBank, it proved to be identical to the previously described L.schi-H1 [GenBank: JF272601]. This haplotype differs from the other haplotype known L.schi-H2 [GenBank: JF272602] in only 8 polymorphic sites, corresponding to 8 indels caused by the microsatellite repeat (TGCT), being present twice in the haplotype 1 between positions 128 and 135 of the alignment and absent in the haplotype 2 .

\section{rDNA ITS-1}

All the lymnaeid individuals showed identical ITS-1 sequences, of 533 bp long and a 59.91\% GC content. This haplotype was compared with two ITS-1 haplotypes of L. schirazensis available in GenBank (HA, HB) and proved to be the same as the previously described L.schi-HA [GenBank: JF272605]. Differences between this haplotype A and L.schi-HB [GenBank: JF272604] are only 1 mutation and two indels.

\section{$m+D N A$ cox 1}

All of the specimens sequenced showed an identical cox 1 nucleotide sequence, of $672 \mathrm{bp}$ and with a biased AT content of $69.5 \%$. This sequence was compared with the four cox 1 haplotypes of L. schirazensis known so far and proved to be identical to the previously described
Positions

G. truncatula coxla (Spain)*
G. truncatula (Germany)**
G. truncatula coxlb (Venezuela)
$11111222 \quad 2333333344 \quad 4556666$

$7811388113 \quad 3122456706 \quad 8172235$

$87175096917814579568 \quad 0304707$

GAACAAAATT AGAGCCCCCT CGAACGT

....................... AGGTGGGGCC GAGATTTTTC TAGGTCC

Figure 4 Nucleotide differences found in the mtDNA cox 1 gene sequence of the Galba truncatula populations studied from Venezuela. Position = numbers (to be read in vertical) refer to variable positions obtained in the alignment made with MEGA 4.0. Nt = nucleotides; Identical $=$; Indel $=-$. Haplotype codes only provisional due to incomplete sequences of the gene. ${ }^{* E M B L: ~ A M 494011 ; ~}{ }^{* * G e n B a n k:}$ EU818799 (incomplete sequence: no haplotype available). 
haplotype L.schi-cox1a [GenBank: JF272607]. Nucleotide and amino acid differences between the four described haplotypes for L. neotropica are listed in Figure 5.

\section{Lymnaea meridensis}

The specimens from Laguna Mucubaji (Mérida State), previously identified as $L$. cousini, proved by ribosomal and mitochondrial DNA marker sequences to be another species to which the name $L$. meridensis has been recently given (Table 1 ).

\section{rDNA ITS-2}

Sequence length and its slightly GC biased average nucleotide composition are $457 \mathrm{bp}$ and $58.85 \%$, respectively. This sequence corresponds to the original haplotype L.mer-H1 of the recently described species $L$. meridensis [EMBL: FN598154]. In the ITS-2 sequence alignment with the haplotype $\mathrm{H} 1$ of $L$. cousini [EMBL: FN598157], a high number (63) of variable positions appear (12.45\%), of which 14 are mutations and 49 indels.

\section{rDNA ITS-1}

ITS-1 length and its slightly GC biased average nucleotide composition are $570 \mathrm{bp}$ and $58.41 \%$, respectively. This sequence corresponds to the haplotype L.mer-HA of L. meridensis [EMBL: FN598159]. In the ITS-1 sequence alignment of L.mer-HA with haplotypes HA and HB of L. cousini [EMBL: FN598157, EMBL: FN598158], a total of 47 variable positions appear $(7.75 \%)$, of which 29 were mutations and 18 indels.

\section{mtDNA cox 1}

This fragment has a length of $672 \mathrm{bp}$ and a highly ATbiased average nucleotide composition of $69.2 \%$, and corresponds to the haplotype cox1a of L. meridensis [EMBL: FN598164]. When compared with the three L. cousini cox 1 provisional haplotypes available in EMBL (cox1a, cox1b and $\operatorname{cox} 1 \mathrm{c}$ ), the differences between both species reach $5.80 \%$. Details on nucleotide and amino acid differences between L. meridensis and L. cousini are listed in Figure 6.

\section{Pseudosuccinea columella}

The specimens from La Linda (Carabobo State) and El Valle (Mérida) previously identified as $P$. columella or ascribed to an undetermined lymnaeid (Lymnaeidae gen. sp.) respectively, proved to be $P$. columella also by ribosomal and mitochondrial DNA markers (Table 1).

\section{rDNA ITS-2}

Two haplotypes were found in the populations studied. All specimens from La Linda, showed identical ITS-2 sequence, of $404 \mathrm{bp}$ and a biased GC content of $60.64 \%$. This ITS-2 sequence is identical to P.col-H2 from Colombia [EMBL: FN598156]. Specimens from El Valle showed the same ITS-2 sequence of $470 \mathrm{bp}$ and $57.02 \%$ GC content, which is identical to P.col-H1 from Puerto Rico [EMBL: FN598155]. Worth mentioning is the presence of $\mathrm{T}$ in the sequence position 6 in the La Linda population, whereas it presents $\mathrm{C}$ in El Valle population. When compared to the ITS-2 of P. columella from Cuba available in the database [GenBank: AY186751], a total of 2 mutations and 9 indels appear.

\section{rDNA ITS-1}

The ITS-1 sequence of both populations was the same, with a length of $536 \mathrm{bp}$ and a slightly GC biased average nucleotide composition of $58.02 \%$. This sequence was identical to that previously described for P.col-HA from Puerto Rico [EMBL: FN598160]. In a pairwise alignment comparison with $P$. columella ITS-1 from Cuba available in the database [GenBank: AY186751: 527 bp long and $58.44 \%$ GC], three indels appear in positions 262, 270 and 276. Worth noting is the presence of $A$ in position 510 , in which whether A or $\mathrm{G}$ were found in Cuba depending on the susceptibility or resistance characteristics of the population, respectively.

\section{mtDNA cox1}

Only one haplotype was detected in all specimens of the populations studied. This fragment has a length of $672 \mathrm{bp}$ and a highly AT-biased average nucleotide composition of

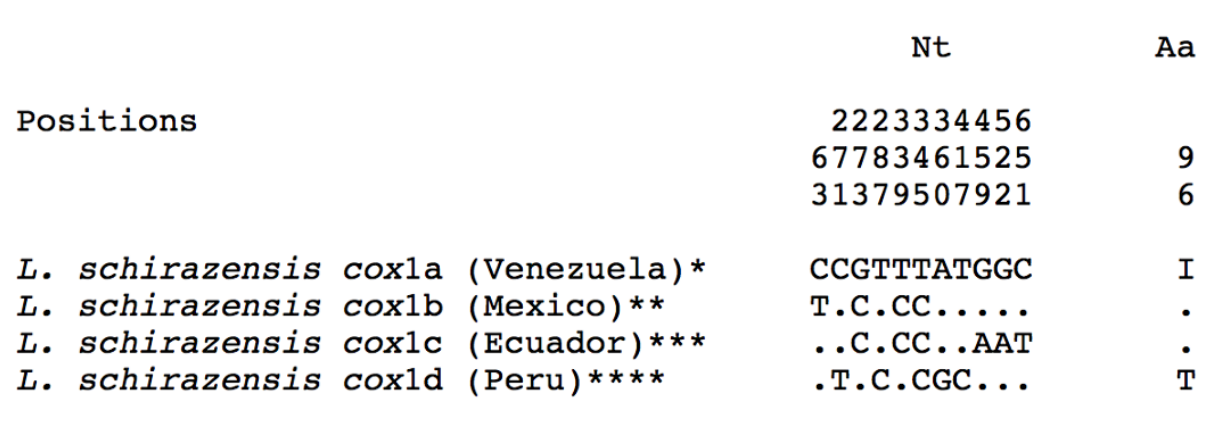

Figure 5 Nucleotide and amino acid differences found in the mtDNA cox 1 gene sequence of the Lymnaea schirazensis populations studied from Venezuela. Position = numbers (to be read in vertical) refer to variable positions obtained in the alignment made with MEGA 4.0. $\mathrm{Nt}=$ nucleotides; $\mathrm{Aa}=$ amino acids; Identical $=$; Indel $=-$. Haplotype codes only provisional due to incomplete sequences of the gene. *GenBank: JF272607, Iran, Spain, Egypt, Mexico, Peru, Dominican Republic; **GenBank: JF272608; ***GenBank: JF272609; ****GenBank: JF272610. 


\section{Nt}

Positions

L. meridensis coxla (Venezuela)

L. cousini coxla (Ecuador)*

L. cousini cox1b (Colombia)**

L. cousini coxlc (Colombia)*** $\begin{array}{lll}111 & 2223333333 \quad 3444445555 & 555666666\end{array}$ $2447778148 \quad 6680123467 \quad 9124880244 \quad 589033345$ $22856811467889816802 \quad 3701394347564006944$

AGTACAAGAA ACCATGGGGC ACTTATGCCC GTCTTTCTG GAAGTGGAGC GTTGGTAAAT GTAATCCTTT AC.CCGT.A GAAGTGGAGT GTTGGTAAAT GTAATCCTTT AC.CCGTAA GAAGTGGAGT GTTGGTAAAT GTAATCCTTT ACTCCGTAA
$\mathrm{Aa}$

2

1
85

II

$\mathrm{V}$.

VN

Figure 6 Nucleotide and amino acid differences found in the mtDNA cox1 gene sequence of Lymnaea meridensis from Venezuela and L. cousini haplotypes. Position = numbers (to be read in vertical) refer to variable positions obtained in the alignment made with MEGA 4.0. Nt $=$ nucleotides; $\mathrm{Aa}=$ amino acids; Identical $=$; Indel $=$-. Haplotype codes only provisional due to incomplete sequences of the gene. ${ }^{*}$ EMBL: FN598161; **EMBL:FN598162; ***EMBL: FN598163.

69.2\%. This sequence was compared with the other two $P$. columella cox 1 sequences of similar length already published and available in databases. Nucleotide and amino acid compositions of $P$. columella from Venezuela are identical to those of the haplotype coxla from Puerto Rico [EMBL: FN598165] and Australia [GenBank: AY227366].

\section{Phylogenetic analysis}

The ML model best fitting the ITS-1 an ITS- 2 combined haplotype dataset was found to be GTR+G (-Ln likelihood $=8346.73598$ ) with a shape parameter (alpha) of 0.6622 , base frequencies for $\mathrm{A}, \mathrm{C}, \mathrm{G}$, and $\mathrm{T}$ of $0.20677,0.27935,0.25969$ and 0.25419 , respectively, and a proportion of invariable sites $=0$. The new ITS-1 sequences obtained from the two Radix species $R$. auricularia and $R$. balthica used were adequately deposited in the database [EMBL: AJ319628 and EMBL: AJ319633, respectively].

The combination of the two internal transcribed spacers in a single dataset generated a robust tree, indicating phylogenetic accordance between the two spacers in the ML tree obtained (Figure 7).

The monophyly of the ITSs haplotypes of the five lymnaeid species of the Galba/Fossaria group found in Venezuela was strongly supported (92/99/99 in NJ/ML/BBP). In this clade, G. truncatula does not appear clustering with other morphologically similar lymnaeids such as the New World L. cubensis and L. neotropica, nor to the phenotypically very close Old World L. schirazensis, but interestingly with L. meridensis, although supports are not high. Lymnaea schirazensis appears in a basal position, as a sister species, in this monophyletic group, although the clustering of the other four Galba/Fossaria species does not appear well supported.

Pseudosuccinea columella appears basal to the two groupings of the stagnicolines, including both Palaearctic and Nearctic species, and the Galba/Fossaria clade which comprises the $F$. hepatica main vector species. The branch of Pseudosuccinea, Galba/Fossaria and stagnicolines appears, moreover, well separated from the
Radix branch, with very high supports (98/96/100 in NJ/ $\mathrm{ML} / \mathrm{BBP})$.

\section{Discussion}

\section{Lymnaeid species reported in Venezuela}

The first report on lymnaeid snail morphology and their habitat in Venezuela, as well as their possible involvement in F. hepatica transmission, appeared early in the 20th century [64]. The presence and involvement of L. cubensis in the transmission of F. hepatica in different parts of the country was described from the mid-last century, mainly with regard to livestock infection [65-68], but also from places where human infection had been reported $[69,70]$. The presence of $P$. columella was detected for the first time in Venezuela somewhat later in a water canal of Maracay city, Aragua State [71]. Numerous multidisciplinary studies on L. cubensis, less numerous on $P$. columella, were performed mainly during the 1980s and first part of the 1990s, including research on distribution, biology, ecology, experimental $F$. hepatica infection, epidemiology and control in western areas [25,27,72-80].

Publications on lymnaeid snails in Venezuela have been more sporadic from the beginning of the 21st century. A high $23.3 \%$ F. hepatica infection prevalence in L. cubensis snails in endemic livestock farms of the Zulia State was noted [81]. Surprisingly high prevalences of $39-43 \%$ were also reported from non-classified lymnaeids in different habitats in another farm of Mérida [82]. After the addition of L. cousini [33] and inclusion of G. truncatula, the four aforementioned species were noted as the only lymnaeids found in Venezuela within the very recent country wide malacological review [34].

\section{A new lymnaeid species scenario obtained by DNA sequencing}

Results obtained by DNA sequencing completely change the lymnaeid scenario in Venezuela. The new scenario of six lymnaeid species contributed in the present paper shows up to which level malacological methods may give 


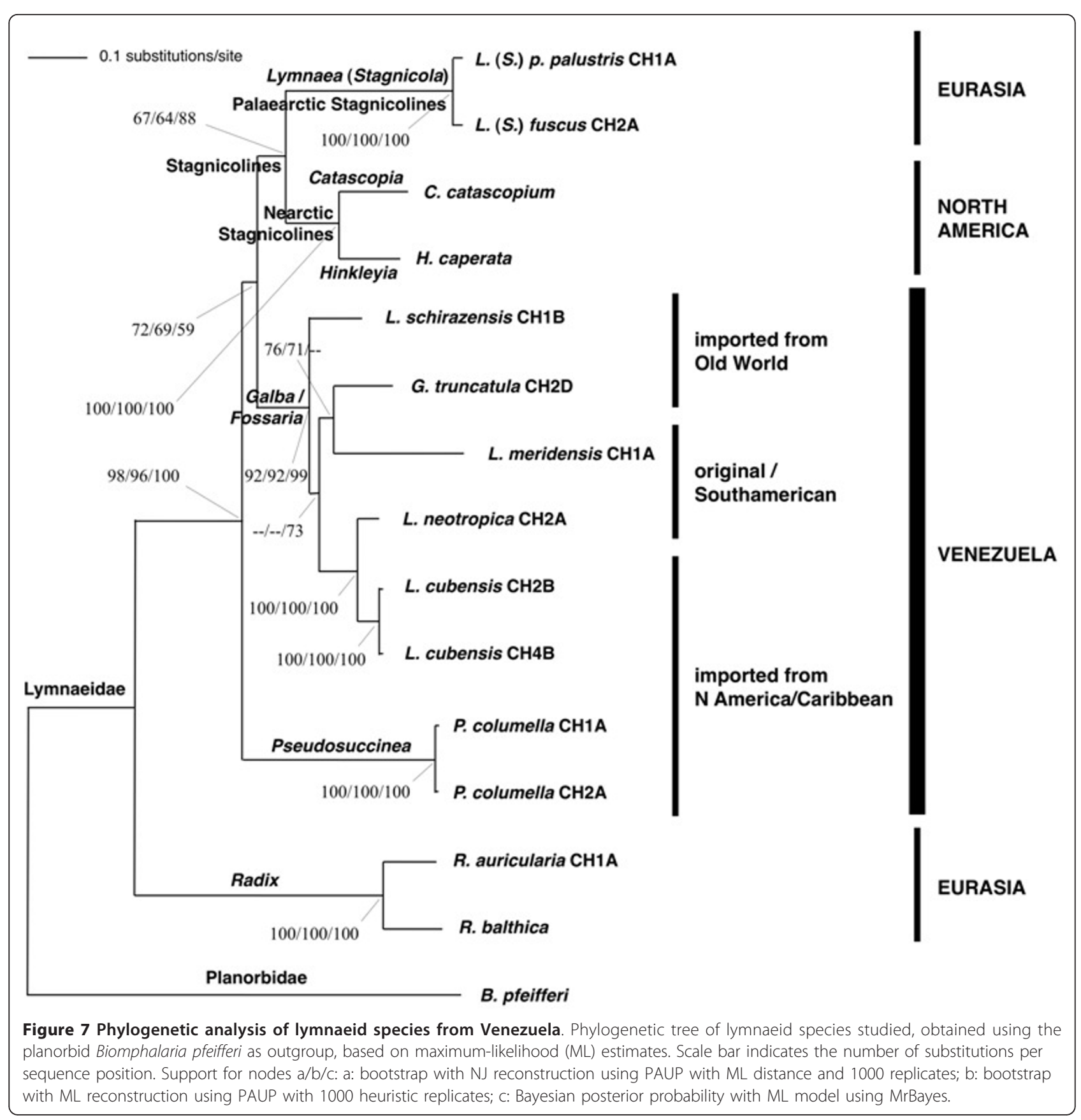

rise to misclassifications when dealing with Lymnaeidae, mainly in problematic groups such as Galba/Fossaria $[28,43]$. Except $P$. columella, a species with peculiar anatomo-morphological and shell shape characteristics, which facilitate its classification mainly in the largest specimens, the remaining L. cubensis, L. neotropica, G. truncatula, L. schirazensis and L. meridensis may be included in Galba/Fossaria (Figure 7). This may explain why the latter four species had been overlooked under the binomium L. cubensis during so much time. These five
Galba/Fossaria species are very similar and almost indistinguishable when young and mid-sized.

This lymnaeid fauna thus appears to be markedly rich when compared to that known in countries of the regions of Central America, the Caribbean and South America. The lymnaeid richness of Venezuela results from the overlap of (i) species of Caribbean and/or Central American origin, such as L. cubensis and P. columella [22], (ii) elements which may be considered typical or perhaps endemic of the Neotropical region, 
such as L. neotropica and L. meridensis [22,28], and (iii) lymnaeids indeed imported by human activities from other continents, such as G. truncatula of European origin and L. schirazensis of Asian origin [9,28,43]. This peculiar Venezuelan lymnaeid fauna is also characterised by two remarkable absences, such as the lack of representatives from the very large Radix and stagnicoline groups (Figure 7) [9,35]. With regard to Radix, Venezuela agrees with its absence in the New World, although given Old World Radix species were imported to the USA time ago [9]. Stagnicolines, widely spread throughout the Palaearctic region [35], are also represented by several species in the Nearctic region [62] and even by one endemic species in Mexico [83]. The absence of stagnicolines in Venezuela supports their inability to colonise warmer latitudes, which agrees with their ecological preferences for cold-mild climates throughout the Holarctic.

\section{Characterisation of Venezuelan lymnaeids}

In L. cubensis, the detection of two different ITS-2 haplotypes highlights two different aspects. The fact that the combined haplotype L.cub-2B, cox $1 \mathrm{~b}$ of the two Aragua populations is identical to that found in South Carolina, USA, suggests a derivation from the same geographical source. Hence, the presence of this combined haplotype in lowlands as a consequence of human importation not very long ago cannot be ruled out. On the contrary, the presence of another combined haplotype differing by only two $\mathrm{A} / \mathrm{T}$ transversions and a different repeat number of an interrupted microsatellite at ITS-2 level (Figure 2) suggests potential adaptive mutations to the high altitude.

The present genetic confirmation of L. neotropica represents the first citation of this species in Venezuela, where it could have been confused with L. cubensis in lowland areas. The morphological similarity between these two species is at such a level that the synonymy of $L$. cubensis and $L$. viatrix was proposed [84] largely before the molecularly-based erection of the new species $L$. neotropica for the old, northern variety B elongata of $L$. viatrix [28]. The finding of L. neotropica in Venezuela expands the geographical distribution of this species, hithterto only described from Peru [28] and Argentina [55], pronouncedly northward. Sequence differences, restricted to only the lack of a dinucleotide microsatellite repeat in the ITS-2 and to 6-7 mutations in cox 1 giving rise to only one different amino acid (Figure 3), may be interpreted as peripheral populations adapted to warmer Venezuelan lowlands of a lymnaeid species apparently very widely distributed throughout South America.

The present study reports the first published DNA sequence confirmation of the presence of G. truncatula in Venezuela, where it has been overlooked at high altitudes but perhaps also confused with $L$. cubensis in mid altitudes around 1900-2000 m. Galba truncatula, of Palaearctic origin and probable man-made importation from a European source [2], has already been described in highlands of other South American countries such as Bolivia [45,47], Peru [18] and Argentina [85,86]. Whereas the detection of only one mutation in the ITS-1 may easily be assumed, the high number of 27 mutations in a 672-bp-long cox 1 fragment when compared to other G. truncatula populations from elsewhere is surprising, even being silent (Figure 4).

Lymnaea schirazensis could have been confused in Venezuela with $L$. cubensis over a long time period and also with G. truncatula since the first detection of the latter in Mérida State in March 2000. Such confusion, however, does not differ from that which occurred in Asia, Africa, Europe, the Caribbean, Central America and South America. A recent large study has demonstrated that $L$. schirazensis and G. truncatula very pronouncedly differ at the level of rDNA and mtDNA, despite its marked anatomical and shell similarity: 130139 nucleotide differences in ITS-2, 134-138 differences in ITS-1, and 57-67 mutations in cox1 [43]. This multidisciplinary study also allowed us to distinguish several phenotypic characteristics which help in the differentiation of both species [43]. The combined haplotype L. schi-1A, cox1a found in Venezuela is the same also detected in other countries such as Iran, Egypt, Spain and the Dominican Republic (Figure 5). This suggests a human importation way from its probable original area in the Near East of Asia whether indirectly through the Dominican Republic in the first decades of the Spanish colonisation period or perhaps directly from the Iberian Peninsula by way of commercial ship activities in subsequent periods [43].

Lymnaea meridensis has recently been described as a new species after the DNA sequencing characterisation of the lymnaeid population of Laguna Mucubaji, Mérida State [22], initially classified as $L$. cousini by malacological techniques [33]. Polymorphic sites are sufficiently numerous as to distinguish two species: 64 nucleotide differences (12.65\% divergence) in ITS-2, 68-71 differences in ITS-1 (11.29-11.73\%), and 37 differences in $\operatorname{cox} 1$ (5.5\%) (Figure 6). Moreover, a detailed morphometric comparison allowed the differentiation of both species by many anatomical characteristics [22]. The finding of another lymnaeid population in the relatively near locality of Paso del Cóndor, at an altitude of 4040 $\mathrm{m}$, recently ascribed to L. cousini [34], may most probably also concern $L$. meridensis. Both $18 \mathrm{~S}$ gene sequence and the phylogenetic analysis based on ITS sequences supported a close evolutionary relationship between $L$. meridensis and L. cousini, suggesting an old common origin and a probable endemic divergence of $L$. meridensis by isolation in Venezuelan highlands [22]. 
Venezuelan $P$. columella show two ITS-2 haplotypes, $\mathrm{H} 1$ and H2, identical to those found in Puerto Rico and Colombia, respectively. The ITS-1 appears to be the same in these three countries. The cox 1 fragment sequence is identical to that in Puerto Rico and Colombia [22] and also Autralia [56]. Pseudosuccinea columella is a rapidly colonising, more aquatic, more heat-tolerant species, considered to originate from Central America, the Caribbean and the southern part of North America. This lymnaeid is widely distributed throughout the world, including North, Central and South America and the Caribbean [26,87], Europe [30], Africa [88], Australia, New Zealand and even Tahiti [29,31]. Its typical presence in botanical gardens suggests its introduction with aquatic plants [88], a phenomenon especially increased in the last decades after the strong development of the trade of aquarium plants [30]. Thus, the presence of $P$. columella in Venezuela should most probably be considered the result of a human introduction in recent times, similarly as in whole South America and in the other continents.

Summing up, DNA sequencing results suggest that (i) the original lymnaeid fauna of Venezuela was indeed only composed by L. meridensis and perhaps also L. neotropica, and that (ii) L. cubensis and P. columella were introduced from the Caribbean area, and (iii) G. truncatula and L. schirazensis from the Old World through human shipping activities in recent times (Figure 7).

\section{Implications for human and animal fascioliasis epidemiology}

Among the six lymnaeid species confirmed to be present in Venezuela, four of them are known to be good vectors of fascioliasis: L. cubensis, L. neotropica, G. truncatula and $P$. columella. This great diversity leads to the need of reopening several epidemiological and distributional aspects of the disease in both humans and animals.

Galba truncatula is considered the original and more efficient F. hepatica vector known [2]. Moreover, it is the only transmitter in the highest human fascioliasis hyperendemic situations known, namely in high altitude Andean areas of Bolivia [89] and Peru [18]. Such high fascioliasis transmission rates have been proved to be the consequence of life cycle modifications in both $F$. hepatica and G. truncatula as an adaptation response to the extreme conditions of the very high altitude [47]. In high altitude areas, fascioliasis in children is usually detected in the advanced chronic stage, which has proved to have a great morbidity impact [90-92]. This poses a question mark of concern with regard to Andean highlands in Venezuela. The recent detection of liver fluke infection in children when performing random surveys in altitude areas of Mérida State [93] suggests that the human fascioliasis situation may be underestimated, mainly in high altitude Andean areas where G. truncatula is present. It is well known that children do not usually attend hospitals or health centres in such rural areas, as proved by the high fascioliasis prevalences and intensities detected in schoolchildren in other Andean countries [16-18]. Besides Mérida State, G. truncatula has also been recently reported from several high altitude areas ranging 2032-2511 m in Táchira State [34], where fascioliasis in cattle is known from lowlands and mid altitudes $[69,94]$ but human infection has never been reported.

Lymnaea cubensis and L. neotropica have also been found to be linked to human infection. Lymnaea cubensis is related to the Caribbean insular epidemiological pattern of human fascioliasis, typically represented by repeated outbreaks in a human hypoendemic area such as in Cuba [11]. In Venezuela, the presence of L. cubensis has been described in several areas of Trujillo State $[24,73,76,78]$ and Portuguesa State [80], where or near to where human infection cases have been sporadically reported, as in highlands of Trujillo State such as Carache, at 1210 m [95,96] and Jajó, at $1796 \mathrm{~m}$ [97], although subsequent surveys did not detect human infection despite the a priori adequate characteristics of the place [98], and lowlands of Portuguesa State such as Guanare, at $183 \mathrm{~m}$ [99]. In the present study, L. cubensis has also been molecularly confirmed to be present in Mérida State up to almost $2000 \mathrm{~m}$ altitude, close to the $2050 \mathrm{~m}$ of the locality of Timotes where human infection was detected in a survey [93].

Lymnaea neotropica was originally described near Lima, Peru [28], where human infection has repeatedly been detected $[100,101]$. Peruvian L. viatrix (= L. neotropica according to [28]) has been shown to transmit fascioliasis both experimentally and in nature [102]. The transmission capacity of L. neotropica has also been molecularly confirmed in Argentina [55]. In Venezuela, DNA sequencing results have demonstrated the presence of $L$. neotropica in lowlands of Carabobo and Falcon States. No human case has so far been described from Falcon, but sporadic human infection has been reported from Valle del Cabriales, at $479 \mathrm{~m}$ [64], where animal infection is endemic [103], and Valencia city, at $430 \mathrm{~m}$ [104].

Pseudosuccinea columella plays a prominent role in $F$. hepatica transmission to animals, as in the Caribbean [105,106] and Brazil [107]. However, its aquatic ecology and habitat preferences seem to explain why this vector species has never been particularly involved in human infection. Interestingly, one mutation at the level of the ITS-1 and another at ITS-2 have proved useful in distinguishing between susceptible and resistant populations of P. columella in Cuba [53], although nothing evidently suggests that these mutations are linked to resistance/susceptibility. The presence of A in position 510 of the pairwise ITS-1 alignment comparison with $P$. columella from Cuba suggests that this species presents $F$. hepatica-susceptible populations in Venezuela, whereas a $T$ in position 6 of the 
ITS-2 indicates that a resistance-linked mutation is also there, at least in La Linda. In Venezuela, P. columella has only been found isolatedly in the States of Aragua (Maracay city), Carabobo (southern part of Valencia Lake), Guárico (Corozo Pando) and Mérida (El Valle) throughout an altitude range of 63-1929 $\mathrm{m}$ [23,34]. This, together with the failure in refinding the populations of Maracay and Valencia in the 2006 survey [34], indicates that this exotic species has apparently not yet been able to further colonise and expand in Venezuela. This may be interpreted as the consequence of still insufficient time after a probable very recent man-made introduction. All in all, there is no evidence to support the idea that $P$. columella was the source of any of the human cases reported in Venezuelan lowlands. Lymnaea cubensis and the very similar L. neotropica were probably in the background of these sporadic infections, almost all concerning adult and old patients, passively detected in health centres in lowland areas. Indeed, L. cubensis has been cited in many lowlands of several States such as Aragua, Falcón, Lara, Portuguesa, Yaracuy, Zulia, Barinas, Trujillo, Sucre and Monagas $[23,34]$.

Experimental infection assays of L. schirazensis have proved that fasciolid larval stages are not able to fully develop within this lymnaeid, which does, therefore, not participate in disease transmission [43]. In Venezuela, the presence of $L$. schirazensis poses a question mark on the geographical distribution of G. truncatula and all other Galba/Fossaria species with whose small and mid-sized specimens it may be very easily confused. One wonders whether unnoticed L. schirazensis specimens could be related to the different fascioliasis transmission capacities linked to different $L$. cubensis specimen size highlighted in mid-altitude localities of Trujillo State [76,77]. Efforts are needed henceforth in Venezuela to clarify the geographical distribution of each Galba/Fossaria species, in order to furnish the baseline on which to correctly analyse the epidemiological characteristics and geographical distribution of both human and animal fascioliasis.

Nothing is known about the potential capacity of $L$. meridensis to transmit $F$. hepatica. However, both very close molecular and phylogenetic relationships with the species L. cousini suggest that it may most probably be involved in fascioliasis transmission [22]. Studies, both in nature and in the laboratory, are needed to assess whether L. meridensis plays a role in fascioliasis transmission.

\section{Conclusions}

Distribution, both in space (latitudinal, longitudinal and altitudinal) and time (seasonal, yearly), of fascioliasis markedly depends on climate factors influencing (i) presence/ absence and population dynamics of the freshwater vector species and (ii) fluke development of free larval stages in freshwater and of parasitic larval stages inside the snail.
Air temperature, rainfall and evapotranspiration are the climate factors that more pronouncedly affect definitive host infection incidence [5]. The only fasciolid present in Venezuela is $F$. hepatica, a fluke species well known due to its preference for temperate and cold climates [2]. This broadly fits with animal fascioliasis reports in Venezuela, which show a clear geographical trend for north-western temperate and colder zones (Figure 1) [23].

Human infection has, however, only been reported from the Capital District, Miranda, Carabobo, Portuguesa, Trujillo, Mérida and Bolívar (Figure 1) [23]. Although human reports are few when compared to other South American countries, such as Chile [14], Bolivia [15-17] and Peru [18,19], a similar altitude pattern appears. In Venezuela, human infection shows more numerous patients, more child involvement and case concentration (same locality, same school) in altitude areas of the western Andean States. Cases appear to be isolated, sporadic and affecting adult and old subjects in the eastern lowland plains. Thus, the altitudinal distribution of this lower human infection situation in Venezuela appears to be similar to that in Ecuador [20] and Argentina [21].

Hence, in Venezuela all evidence indicates that altitude is the main factor influencing fascioliasis distribution, and therefore highlights importance of accurately assessing the altitudinal distribution range of each of the lymnaeid vector species. Altitudinal data for each species noted in Table 1 furnish a first approach. The new scenario provided here implies the need to completely reassess the distribution of each one of the six lymnaeid species in space and time with the help of the DNA marker tools. Lymnaeid mapping becomes a priority to determine the distribution of human and animal fascioliasis inside Venezuela. The overlap of G. truncatula, L. cubensis and probably also L. neotropica in temperate and cold zones suggests that there is a higher risk for human infection in mid and high altitude rural areas. Appropriate human surveys, mainly focusing on children, in such areas are evidently needed to verify whether overlooked fascioliasis prevalence may exist.

The overlap, in the same endemic area, of more than one lymnaeid vector species with different ecological requirements and population dynamics will unfortunately make the application of mathematical forecast indexes [12] more complicated. Increased difficulties may similarly be expected for remote sensing and geographical information system (RS-GIS) methods [13] to obtain accurate results useful for fascioliasis risk assessment and monitoring.

\section{Acknowledgements}

Studies funded by Projects No. BOS2000-0570-C02-02, No. BOS2002-01978, No. SAF2006-09278 and SAF No. 2010-20805 of the Ministry of Education 
and Ministry of Science and Innovation, Madrid; and by the Red de Investigación de Centros de Enfermedades Tropicales - RICET (Projects No. C03/04, No. ISCIII2005-PI050574 and No. ISCIII-RETIC RD06/0021/0017 of the Programa de Redes Temáticas de Investigación Cooperativa RETICS/FEDER), FIS, Ministry of Health, Madrid, Spain. Research activities in the "El Joque" Experimental Farm Station funded by Project No. FA-464-09-03-C of the Consejo de Desarrollo Científico Humanístico, Tecnológico y de las Artes, Universidad de Los Andes (C.D.C.H.T.A.-ULA), Mérida, Venezuela. Part of this work was made possible thanks to personal fellowships funded to P. Artigas and C. González by the Agencia Española de Cooperación Internacional (AECI), Ministry of Foreign Affairs, Madrid, Spain. Research stay of C. González in Parasitology Department of Valencia University additionally funded by the Universidad de los Andes-CONICIT, Venezuela. Thanks are given to Dr. A.M. Pérez (Maracay, Aragua State, Venezuela) for furnishing lymnaeids from Falcon State and and Dr. J.P. Pointier (Perpignan, France) for those from Aragua State, Carabobo State and Laguna Mucubaji of Mérida State.

Field work activities performed within the worldwide initiative of WHO (Headquarters Geneva, Switzerland) against human fascioliasis. Joint coordination activities carried out within Project No. RLA5049 of the International Atomic Energy Agency (Animal Production and Health Section, Joint FAO/IAEA Division of Nuclear Techniques in Food and Agriculture, Department of Nuclear Sciences and Applications, IAEA Headquaters Vienna, Austria). Technical support provided by the Servicio Central de Secuenciación para la Investigación Experimental (SCSIE) of the Universidad de Valencia (Dr. A. Martínez).

\section{Author details}

'Departamento de Parasitología, Facultad de Farmacia, Universidad de Valencia, Av. Vicente Andrés Estellés s/n, 46100 Burjassot - Valencia, Spain. ${ }^{2}$ Laboratorio de Investigaciones Parasitológicas "Dr. Jesús Moreno Rangel", Cátedra de Parasitología, Departamento de Microbiología y Parasitología, Facultad de Farmacia y Bioanálisis, Universidad de Los Andes, Urb. Campo de Oro, 5101, Mérida, Estado Mérida, Venezuela.

\section{Authors' contributions}

MDB contributed to the design of the study, participated in field collections, analysed the sequences, performed the phylogenetic study, and helped to draft the manuscript. CG participated in field collections, contributed to epidemiological studies, and performed the local literature search. PA carried out the DNA sequencing processes. SMC designed and supervised the study, participated in field collections, performed the epidemiological analyses, and wrote the manuscript. All authors read and approved the final manuscript.

\section{Competing interests}

The authors declare that they have no competing interests.

Received: 15 March 2011 Accepted: 14 October 2011

Published: 14 October 2011

\section{References}

1. Mas-Coma S, Bargues MD, Valero MA: Fascioliasis and other plant-borne trematode zoonoses. Int J Parasitol 2005, 35:1255-1278.

2. Mas-Coma S, Valero MA, Bargues MD: Fasciola, lymnaeids and human fascioliasis, with a global overview on disease transmission, epidemiology, evolutionary genetics, molecular epidemiology and control. Adv Parasitol 2009, 69:41-146.

3. World Health Organization: Control of foodborne trematode infections. WHO Techn Rep Ser 1995, 849:1-157.

4. Mas-Coma S, Valero MA, Bargues MD: Effects of climate change on animal and zoonotic helminthiases. Rev Sci Techn Off Int Epiz 2008, 27:443-457.

5. Mas-Coma S, Valero MA, Bargues MD: Climate change effects on trematodiases, with emphasis on zoonotic fascioliasis and schistosomiasis. Vet Parasitol 2009, 163:264-280.

6. Ollerenshaw CB: Forecasting liver-fluke disease. In The Effects of Meteorological Factors upon Parasites, Symposium of the British Society for Parasitology. Volume 12. Edited by: Taylor AR, Muller R. Oxford: Blackwell Scientific Publications; 1974:33-52.

7. Valero MA, Mas-Coma S: Comparative infectivity of Fasciola hepatica metacercariae from isolates of the main and secondary reservoir animal host species in the Bolivian Altiplano high human endemic region. Folia Parasitol 2000, 47:17-22.

8. Valero MA, Darce NA, Panova M, Mas-Coma S: Relationships between host species and morphometric patterns in Fasciola hepatica adults and eggs from the Northern Bolivian Altiplano hyperendemic region. Vet Parasitol 2001, 102:85-100.

9. Bargues MD, Vigo M, Horak P, Dvorak J, Patzner RA, Pointier JP, Jackiewicz M, Meier-Brook C, Mas-Coma S: European Lymnaeidae (Mollusca: Gastropoda), intermediate hosts of trematodiases, based on nuclear ribosomal DNA ITS-2 sequences. Inf Genet Evol 2001, 1:85-107.

10. Bargues MD, Mas-Coma S: Reviewing lymnaeid vectors of fascioliasis by ribosomal DNA sequence analyses. J Helminthol 2005, 79:257-267.

11. Mas-Coma S: Epidemiology of fascioliasis in human endemic areas. $J$ Helminthol 2005, 79:207-216.

12. Fuentes MV, Valero MA, Bargues MD, Esteban JG, Angles R, Mas-Coma S: Analysis of climatic data and forecast indices for human fascioliasis at very high altitude. Ann Trop Med Parasitol 1999, 93:835-850.

13. Fuentes MV, Malone JB, Mas-Coma S: Validation of a mapping and predicting model for human fasciolosis transmission in Andean very high altitude endemic areas using remote sensing data. Acta Trop 2001, 79:87-95.

14. Apt W, Aguilera X, Vega F, Alcaino H, Zulantay I, Apt P, Gonzalez V, Retamal, Rodriguez J, Sandoval J: Prevalencia de fascoliasis en humanos, caballos, cerdos y conejos silvestres en tres provincias de Chile. Bol Of Sanit Panam 1993, 115:405-414.

15. Hillyer GV, Soler de Galanes M, Rodriguez-Perez J, Bjorland J, Silva de Lagrava M, Guzman SR, Bryan RT: Use of the Falcon ${ }^{\mathrm{TM}}$ assay screening test-enzyme-linked immunosorbent assay (FAST-ELISA) and the enzymelinked immunoelectrotransfer blot (EITB) to determine the prevalence of human fascioliasis in the Bolivian altiplano. Am J Trop Med Hyg 1992, 46:603-609.

16. Esteban JG, Flores A, Angles R, Strauss W, Aguirre C, Mas-Coma S: A population-based coprological study of human fascioliasis in a hyperendemic area of the Bolivian Altiplano. Trop Med Int Health 1997, 2:695-699.

17. Esteban JG, Flores A, Angles R, Mas-Coma S: High endemicity of human fascioliasis between Lake Titicaca and La Paz valley, Bolivia. Trans Roy Soc Trop Med Hyg 1999, 93:151-156.

18. Esteban JG, Gonzalez C, Bargues MD, Angles R, Sanchez C, Naquira C, MasComa S: High fascioliasis infection in children linked to a man-made irrigation zone in Peru. Trop Med Int Health 2002, 7:339-348.

19. González LC, Esteban JG, Bargues MD, Valero MA, Ortiz P, Naquira C, MasComa S: Hyperendemic human fascioliasis in Andean valleys: An altitudinal transect analysis in children of Cajamarca province, Peru. Acta Trop 2011, 120:119-129.

20. Trueba G, Guerrero T, Fornasini M, Casariego I, Zapata S, Ontaneda S, Vasco L: Detection of Fasciola hepatica infection in a community located in the Ecuadorian Andes. Am J Trop Med Hyg 2000, 62:518.

21. Mera y Sierra R, Agramunt V, Cuervo P, Mas-Coma S: Human fascioliasis in Argentina: retrospective overview, critical analysis and baseline for future research. Parasit Vector 2011, 4:104.

22. Bargues MD, Artigas P, Khoubbane M, Mas-Coma S: DNA sequence characterisation and phylogeography of Lymnaea cousini and related species, vectors of fascioliasis in northern Andean countries, with description of Lymnaea meridensis n. sp. (Gastropoda: Lymnaeidae). Parasit Vector 2011, 4:132.

23. González LC, Blanco MA, Gil F, Castro T, Mas-Coma S: Fascioliasis in Venezuela: past and present knowledge on human and animal infection. In Zoonotic Fascioliasis in Latin America. Edited by: Mas-Coma S, Bargues MD, Viljoen GJ. Vienna-Roma: IAEA-FAO; 2011:

24. Morales G, Pino LA: Infection de Lymnaea cubensis par Fasciola hepatica dans une région d'altitude au Venezuela. Ann Parasitol Hum Comp 1983, 58:27-30.

25. Morales G, Pino LA, Rodriguez E: Diseño de estrategias de control para poblaciones de Lymnaea cubensis Pfeiffer, 1839 y Lymnaea columella Say, 1817. Bol Dir Malariol Saneam Ambient 1983, 23:11-17.

26. Malek EA: Snail hosts of schistosomiasis and other snail-transmitted diseases in tropical America: a manual. Washington: Pan American Health Organization, Scientific Publication; 1985:478:325.

27. Chrosciechowski P: Problema de la fascioliasis en Venezuela: su aspecto malacológico. Bol Dir Malariol Saneam Amb 1987, 27:53-58. 
28. Bargues MD, Artigas P, Mera y Sierra R, Pointier JP, Mas-Coma S: Characterisation of Lymnaea cubensis, L. viatrix and L. neotropica n. sp. the main vectors of Fasciola hepatica in Latin America, by analysis of their ribosomal and mitochondrial DNA. Ann Trop Med Parasitol 2007, 101:621-641.

29. Hubendick B: Recent Lymnaeidae. Their variation, morphology, taxonomy, nomenclature, and distribution. 1951, 3(1):1-223, Kungliga Svenska Vetenskapsakademiens Handlingar, Fjärde Serien; + 5 pl.

30. Pointier JP, Cousteau C, Rondelaud D, Theron A: Pseudosuccinea columella (Say, 1817) (Gastropoda, Lymnaeidae), snail host of Fasciola hepatica: first record for France in the wild. Parasitol Res 2007, 101:1389-1392.

31. Baldock FC, Arthur RJ: A survey of fascioliasis in beef cattle killed at abattoirs in southern Queensland. Austr Vet J 1985, 62:324-326.

32. Artigas $P$, Bargues MD, Mera y Sierra R, Agramunt VH, Mas-Coma S: Characterisation of fascioliasis lymnaeid intermediate hosts from Chile by DNA sequencing, with emphasis on Lymnaea viator and Galba truncatula. Acta Trop 2011, 120:245-257.

33. Pointier JP, Noya O, Amarista M, Theron A: Lymnaea cousini Jousseaume, 1887 (Gastropoda: Lymnaeidae): first record for Venezuela. Mem Inst Oswaldo Cruz 2004, 99:567-569.

34. Pointier JP, Noya O, Alarcon de Noya B, Theron A: Distribution of Lymnaeidae (Mollusca: Pulmonata), intermediate snail hosts of Fasciola hepatica in Venezuela. Mem Inst Oswaldo Cruz 2009, 104:790-796.

35. Bargues MD, Horak P, Patzner RA, Pointier JP, Jackiewicz M, Meier-Brook C, Mas-Coma S: Insights into the relationships of Palaearctic and Nearctic lymnaeids (Mollusca: Gastropoda) by rDNA ITS-2 sequencing and phylogeny of stagnicoline intermediate host species of Fasciola hepatica. Parasite 2003, 10:243-255

36. Samadi S, Roumegoux A, Bargues MD, Mas-Coma S, Yong M, Pointier JP: Morphological studies of lymnaeid snails from the human fascioliasis endemic zone of Bolivia. J Moll Stud 2000, 66:31-44.

37. Mas-Coma S, Bargues MD: Populations, hybrids and the systematic concepts of species and subspecies in Chagas disease triatomine vectors inferred from nuclear ribosomal and mitochondrial DNA. Acta Trop 2009, 110:112-136.

38. Puslednik L, Ponder WF, Dowton M, Davis AR: Examining the phylogeny of the Australasian Lymnaeidae (Heterobranchia: pulmonata: Gastropoda) using mitochondrial, nuclear and morphological markers. Mol Phylogenet Evol 2009, 52:643-659.

39. Kane RA, Stothard JR, Emery AM, Rollinson D: Molecular characterization of freshwater snails in the genus Bulinus: a role for barcodes? Parasit Vector 2008, 1:15.

40. Paraense WL: Lymnaea columella in northern Brazil. Mem Inst Osw Cruz 1983, 78:477-482.

41. Pointier JP, Cazzaniga NJ, González-Salas C, Gutiérrez A, Arenas JA, Bargues MD, Mas-Coma S: Anatomical studies of sibling species within Neotropical lymnaeids snail intermediate hosts of fascioliasis. Mem Inst Osw Cruz 2006, 101:431-435.

42. Rondelaud D, Vignoles $P$, Dreyfuss G: La limnée tronquée, un mollusque d'intérêt médical et vétérinaire. Limoges: Presses Universitaires de Limoges; 2009, 283.

43. Bargues MD, Artigas $P$, Khoubbane $M$, Flores $R$, Glöer $P$, Rojas-Garcia $R$, Ashrafi K, Falkner G, Mas-Coma S: Lymnaea schirazensis, an overlooked snail distorting fascioliasis data: Genotype, phenotype, ecology, worldwide spread, susceptibility, applicability. PLOS ONE 2011, 6(9): e24567, (33 pp. + 3 Suppl. Tables + 5 Suppl. Figures)

44. Bargues MD, Mangold A, Muñoz-Antoli C, Pointier JP, Mas-Coma S: SSU rDNA characterization of lymnaeid snails transmitting human fascioliasis in South and Central America. J Parasitol 1997, 83:1086-1092.

45. Bargues MD, Mas-Coma S: Phylogenetic analysis of lymnaeid snails based on 18S rDNA sequences. Mol Biol Evol 1997, 14:569-577.

46. Bargues MD, Artigas P, Jackiewicz M, Pointier JP, Mas-Coma S: Ribosomal DNA ITS-1 sequence analysis of European stagnicoline Lymnaeidae (Gastropoda). Heldia (Münchner Malakologische Mitteilungen), München 2006, 6(1/2):29-40

47. Mas-Coma S, Funatsu IR, Bargues MD: Fasciola hepatica and lymnaeid snails occurring at very high altitude in South America. Parasitology 2001 123:S115-S127.

48. Folmer O, Black M, Hoch W, Lutz R, Vrijenhoek R: DNA primers for amplification of mitochondrial cytochrome c oxidase subunit I from diverse metazoan invertebrates. Mol Marine Biol Biotech 1994, 3:294-299.
49. Sanger $F$, Nicklen $S$, Coulson AR: DNA sequencing with chain-terminating inhibitors. Proc Natn Acad Sc USA 1977, 74:5463-5467.

50. Thompson JD, Higgins DG, Gibson TJ: CLUSTAL W: improving the sensitivity and progressive multiple sequence alignment through sequence weighting, positions-specific gap penalties and weight matrix choice. Nucl Acids Res 1994, 22:4673-4680

51. Tamura K, Dudley J, Nei MB, Kumar S: MEGA4: Molecular Evolutionary Genetic Analysis (MEGA) sofware version 4.0. Mol Biol Evol 2007, 24:1596-1599.

52. Staden R, Judge DP, Bonfield JK: Sequence assembly and finishing methods. Meth Bioch Anal 2001, 43:302-322.

53. Gutierrez A, Pointier JP, Fraga J, Jobet E, Modat S, Perez RT, Yong M Sanchez J, Loker ES, Theron A: Fasciola hepatica: identification of molecular markers for resistant and susceptible Pseudosuccinea columella snail hosts. Exp Parasitol 2003, 105:211-218.

54. Albrecht C, Wolf C, Glöer P, Wilke T: Concurrent evolution of ancient siste lakes and sister species: the freshwater gastropod genus Radix in lakes Ohrid and Prespa. Hydrobiologia 2008, 615:157-167.

55. Mera y Sierra R, Artigas P, Cuervo P, Deis E, Sidoti L, Mas-Coma S, Bargues MD: Fascioliasis transmission by Lymnaea neotropica confirmed by nuclear rDNA and mtDNA sequencing in Argentina. Vet Parasitol 2009, 166:73-79.

56. Remigio EA, Hebert PD: Testing the utility of partial COI sequences for phylogenetic estimates of gastropod relationships. Mol Phylogenet Evol 2003, 29:641-647.

57. Akaike $\mathrm{H}$ : A new look at the statistical model identification. leee Trans Automat Control 1974, 19:716-723.

58. Posada D, Buckley TR: Model selection and model averaging in phylogenetics: advantages of the AIC and Bayesian approaches over likelihood ratio tests. Syst Biol 2004, 53:793-808.

59. Posada D: jModelTest: phylogenetic model averaging. Mol Biol Evol 2008 25:1253-1256.

60. Saitou N, Nei M: The neighbor-joining method: a new method for reconstructing phylogenetic trees. Mol Biol Evol 1987, 4:406-425.

61. Ronquist F, Huelsenbeck JP: MrBayes 3: Bayesian phylogenetic inference under mixed models. Bioinformatics 2003, 19:1572-1574.

62. Remigio EA, Blair D: Relationships among problematic North American stagnicoline snails (Pulmonata: Lymnaeidae) reinvestigated using nuclear ribosomal DNA internal transcribed spacer sequences. Can J Zool 1997, 75:1540-1545.

63. De Jong RJ, Morgan JAT, Paraense WL, Pointier JP, Amarista M, AyehKumi PFK, Babiker A, Barbosa CS, Bremond Ph, Canese AP, Pereira de Souza C, Dominguez C, File S, Gutierrez A, Incani RN, Kawano T, Kazibwe F, Kpikpi J, Lwambo NJS, Mimpfoundi R, Njiokou F, Poda JN, Sene M, Velasquez LE, Yong M, Adema CM, Hofkin BV, Mkoji GM, Loker ES: Evolutionary relationships and biogeography of Biomphalaria (Gastropoda: Planorbidae) with implications regarding its role as host of the human bloodfluke, Schistosoma mansoni. Mol Biol Evol 2001, 18:2225-2239.

64. Bello H: Sobre la distomatosis hepática en Venezuela. Vargas 1916, 7:7

65. Lutz A: Moluscos de agua dulce recogidos y observados en Venezuela. In Estudios de Zoología y Parasitología Venezolanas Edited by: Rio de Janeiro 1928, 75-84

66. Lutz A: Estudios de Zoología y Parasitología Venezolanas. Reimpresión de la edición de 1928 ordenada por la Universidad Central de Venezuela en Homenaje al Dr. Lutz en el centenario de su muerte. Caracas: Universidad Central de Venezuela; 1955, 137.

67. Vergani F: Datos biológicos experimentales sobre el caracol Lymnaea (Galba) cubensis P. 1911. Rev Vet Venezuela 1957, 52:193-210.

68. Martinez R, Miranda R: Aspectos de la reproducción en moluscos pulmonados del área Metropolitana de Caracas. Estudio de Caracas, Univ Cent Venezuela 1968, 1:123-165

69. Ramirez-Villamediana JJ, Vergani F: Contribución al estudio del ciclo evolutivo de la Fasciola hepática en Venezuela. Rev Ganad Col 1949, 3:817-826.

70. Briceño Rossi AL: Trabajo experimental sobre Fasciola hepatica. Rev San Asis Soc 1950, 14:380-388

71. Malek EA, Chrosciechowski P: Lymnaea (Pseudosuccinea) columella from Venezuela, and notes on distribution of Pseudosuccinea. Nautilus 1964 78:54-56. 
72. Chavez K, Surumay Q, Olivares R, Montiel N: Prevalencia de distomatosis hepática en fincas del Distrito Mara del estado Zulia. Vet Trop 1979, 4:52-63.

73. Morales G, Pino LA: Lymnaea cubensis Pfeiffer, 1839, Hospedador Intermediario de Fasciola hepatica en la zona Alta de Los Andes Trujillanos, Venezuela. Bol Dir Malariol Saneam Ambient 1981, 21:1-9.

74. Morales G, Pino LA: Fasciola hepatica: Aspectos ecoepidemiológicos de interés para el desarrollo de estrategias de control. In Ganadería Mestiza de Doble Propósito. Edited by: González Stognaro C. Astro Data; 1992:301-329.

75. Morales G, Rodriguez E, Pino LA, Perdomo L: Estadísticas vitales de Lymnaea cubensis Pfeiffer, 1839 en condiciones de laboratorio. Bol Dir Malariol Saneam Ambient 1985, 25:89-99.

76. Morales G, Pino LA, Morales J: Distribución de las redias y cercarias de Fasciola hepatica en una población silvestre de Lymnaea cubensis del Occidente de Venezuela. Acta Cient Venez 1986, 37:535-541.

77. Morales G, Pino LA, Perdomo L: Utilidad del conocimiento del tamaño del molusco Lymnaea cubensis en la implementación de programas de control de la distomatosis hepática. Rev Fac Cien Vet UCV 1986, 33:28-37.

78. Pino LA, Morales G: Habitats de Lymnaea cubensis Pfeiffer, 1839, hospedador intermediario de Fasciola hepatica, detectados en el estado Trujillo, Venezuela. Acta Cient Venez 1982, 33:61-65.

79. Pino LA, Morales G, Marquez A: Presencia de Lymnaea cubensis hospedador intermediario de Fasciola hepatica en el Municipio La Cañada de Urdaneta, Estado Zulia. Vet Trop 1995, 20:85-93.

80. Melendez R, Coronado A, Diaz J, Crespo G: Aspectos epidemiológicos de la fascioliasis bovina en el centro-occidente venezolano; con énfasis en la prevalencia del trematode y de su hospedador intermediario. Acta Cien Venez 1983, 34:65-71.

81. Fuenmayor A, Simoes D, Gonzalez R, Chirinos A: La Distomatosis hepática y su asociación con los factores de riesgo en los Municipios Mara y Páez del estado Zulia, Venezuela. Rev Cient FCV-LUZ 2000, 103:183-190.

82. Nieves E, Rondón M, Zamora E, Salazar M: Fasciola hepatica en la zona alta de Mérida, Venezuela. Rev Elec Vet REDVET 2005, 6(12)[http://www. veterinaria.org/revistas/redvet/n121205.html].

83. Gomez Agudelo T, Perez Reyes R, Zeron Braco F: Fasciolosis en México. Estado actual y huéspedes intermediarios. Rev Latinoamer Microbiol 1978, 20:121-127.

84. Paraense WL: Lymnaea viatrix: a study of topotypic specimens (Mollusca: Lymnaeidae). Rev Bras Biol 1976, 36:419-428.

85. Bargues MD, Mera y Sierra R, Gomez HG, Artigas P, Mas-Coma S: Ribosomal DNA ITS-1 sequencing of Galba truncatula (Gastropoda: Lymnaeidae) and its potential impact on fascioliasis transmission in Mendoza, Argentina. Animal Biodiv Conserv 2006, 29:191-194

86. Bargues MD, Mera y Sierra R, Gomez HG, Artigas P, Mas-Coma S: Caracterización molecular de Galba truncatula, vector principal de la Fascioliasis, en Argentina. Implicaciones en salud pública. Enf Emerg, Barcelona 2007, 9:77-82.

87. Paraense WL: Lymnaea viatrix and Lymnaea columella in the Neotropical region: a distributional outline. Mem Inst Oswaldo Cruz 1982, 77:181-188.

88. Brown D: Freshwater Snails of Africa and Their Medical Importance. London: Taylor \& Francis Ltd; 2 1994, 608

89. Mas-Coma S, Angles R, Esteban JG, Bargues MD, Buchon P, Franken M, Strauss W: The Northern Bolivian Altiplano: a region highly endemic for human fascioliasis. Trop Med Int Health 1999, 4:454-467.

90. Valero MA, Santana M, Morales M, Hernandez JL, Mas-Coma S: Risk of gallstone disease in advanced chronic phase of fascioliasis: an experimental study in a rat model. J Inf Dis 2003, 188:787-793.

91. Valero MA, Navarro M, Garcia-Bodelon MA, Marcilla A, Morales M, Garcia JE, Hernandez JL, Mas-Coma S: High risk of bacterobilia in advanced experimental chronic fasciolosis. Acta Trop 2006, 100:17-23.

92. Valero MA, Girones N, Garcia-Bodelon MA, Periago MV, Chico-Calero I, Khoubbane M, Fresno M, Mas-Coma S: Anemia in advanced chronic fasciolosis. Acta Trop 2008, 108:35-43.

93. Alarcon de Noya B, Rojas E, Colmenares C, Morales C, Contreras R, Valero SK, Hernandez D, Briceño S, Scorza JV, Noya O: Brote familiar de fascioliasis en Venezuela. Bol Malariol Salud Amb 2007, 47:47-54.

94. Perruolo G, Perdomo E, Silva Coronado J: Estudio de la Fasciola hepatica en el Estado Táchira, Venezuela. Incidencia y prevalencia en la zona sur del Estado Táchira. Rev Cient UNET 1987, 1:14-19.
95. Tombazzi C, Abdul-Hadi S, Lecuna V, Contreras R, Marquez D: Endoscopic retrograde cholangiopancreatography in hepatic fascioliasis. GEN 1994, 48:278-80.

96. Abdul-Hadi S, Contreras R, Tombazzi C, Alvarez M, Melendez M: Hepatic fascioliasis: case report and review. Rev Inst Med Trop Sao Paulo 1966, 14:69-73.

97. Scorza JV, Villegas E, Morales C: Fascioliasis hepática en el Estado Trujillo, Venezuela. Un segundo caso clínico. Arch Venez Med Trop 1999, 3:9-13.

98. Abdul-Hadi S, Figueira I, Madera C, Olaizola C, Contreras R, Sanchez MA, Colmenares C, Safar ML: Estudio de la fascioliasis hepática humana y parasitosis intestinales en el caserío Mesa Arriba del municipio Carache, estado Trujillo, Venezuela. Rev Soc Venez Microbiol 2009, 29:128-132.

99. Rodriguez A, Gonzalez H: Sobre un nuevo caso humano de fascioliasis hepática en Venezuela. Rev Inst Nac Hig 1975, 8:111-114.

100. Blancas G, Terashima A, Maguina C, Vera L, Alvarez H, Tello R: Fasciolosis humana y compromiso gastrointestinal: estudio de 277 pacientes en el Hospital Nacional Cayetano Heredia 1970-2002. Rev Gastroenterol Perú 2004, 24:143-157.

101. Marcos LA, Romani L, Florencio L, Terashima A, Canales M, Nestares J, Huayanay L, Gotuzzo E: Zonas hiperendémicas y mesoendémicas de la infección por Fasciola hepatica aledañas a la ciudad de Lima: Una enfermedad emergente? Rev Gastroenterol Perú 2007, 27:21-26.

102. Tantalean M, Huiza A, Capuñay R: Los hospederos intermediarios de Fasciola hepatica en el Perú: estudio de la infección natural y experimental de Lymnaea viator, L. diaphana y Physa venustula. Biota 1974, 10:243-250.

103. Mayaudon TH, Gallo P: Algunas consideraciones sobre las helmintozoonosis en Venezuela. Rev Fac Cien Vet, Univ Cent Venezuela 1963, 20:5-21.

104. Incani RN, Vieira JM, Pacheco M, Planchart S, Amarista M, Lazdins J: Human infection by Fasciola hepatica: report of a geriatric case. Invest Clin 2003, 44:255-260.

105. De Leon-Dancel D: Life history of Lymnaea columella (Say) and its experimental infection with Fasciola hepatica (L.). J Agric Univ Puerto Rico 1970, 54:297-305.

106. Ferrer J, Perera G, Yong M, Amador O: Life tables of Fossaria cubensis and Pseudosuccinea columella, intermediate hosts of Fasciola hepatica in Cuba. J Med Appl Malacol 1989, 1:189-194.

107. Coelho LHL, Lima WS: Population dynamics of Lymnaea columella and its natural infection by Fasciola hepatica in the State of Minas Gerais, Brazil. J Helminthol 2003, 77:7-10.

doi:10.1186/1756-3305-4-200

Cite this article as: Bargues et al:: A new baseline for fascioliasis in Venezuela: lymnaeid vectors ascertained by DNA sequencing and analysis of their relationships with human and animal infection. Parasites \& Vectors 2011 4:200.

\section{Submit your next manuscript to BioMed Central and take full advantage of:}

- Convenient online submission

- Thorough peer review

- No space constraints or color figure charges

- Immediate publication on acceptance

- Inclusion in PubMed, CAS, Scopus and Google Scholar

- Research which is freely available for redistribution

Submit your manuscript at www.biomedcentral.com/submit
C Biomed Central 